\title{
Teaching natural science in the foundation phase: Teachers' understanding of the natural science curriculum
}

\begin{abstract}
This study explores foundation phase teachers' understanding of the natural science curriculum within the life skills learning programme. The theoretical framework for this study is entrenched in the relationship between the intended and the implemented curriculum. The Zone of Feasible Innovation (ZFI) is the proposed theory of implementation and states that implementation of the intended curriculum is very difficult if teachers do not have the capacity to implement it. The study seeks to determine where teachers are operating within their ZFI. Data was collected through questionnaires, interviews as well as a rating scale for teachers. The findings show that teachers are confident to teach content that they have been teaching for a long time, but are reluctant to introduce new science topics or new methods of instruction. This reluctance impacts on their ability to implement new innovations in science teaching. However, there are signs that their ZFI has progressed to include certain new practices.
\end{abstract}

Keywords: curriculum implementation; capacity to innovate; profile of implementation and zone of feasible innovation.

Saritha Beni, Embury Institute for TeacherEducation, Durban.E-mail: SarithaB@eite.ac.za. Michèle Stears, School of Education, University of KwaZulu-Natal.E-mail: stearsm@ukzn. ac.za. Angela James, School of Education, University of KwaZulu-Natal. E-mail: jamesa1@ ukzn.ac.za. 


\section{Introduction}

Recent developments in South Africa echo worldwide transformation trends in science education. In the United Kingdom Target 1 for science in the National Curriculum has apportioned much precedence to scientific investigations (Department of Education and Employment, 1999). In the United States, the American Association for the Advancement of Science (AAAS) and the National Research Council (NRC) sanction science curricula that actively engage learners using an inquiry based approach. (American Association for the Advancement of Science, 1993 and National Research Council, 1996). The New Zealand Curriculum Framework maintains that science is essential to understanding our world and active participation in science fosters understanding (New Zealand Ministry of Education, 2009).

Science and its related fields of study are viewed as a scarce skill in South Africa. According to Boshoff and Mouton (2003: 231) -

... there appears to be a gradual ageing of the publishing scientific workforce with a low level of new entrants into the science system (especially natural science).

Braund and Reiss (2006: 1373) recognise the problem exists in many developed countries of the world as well, where fewer learners are choosing to study science at higher levels and as a career. Our contention is that the solution to increasing the number of science graduates lies within the school system. This can only be achieved if learners have an interest in the subject and if that interest is nurtured during the early years of schooling. This interest and love for science has to be developed and nurtured from the time the child enters the schooling system in Grade R. This is necessary, not only to make daily decisions but also to meet the demands of the global economy.

According to the Revised National Curriculum Statements (RNCS) (DoE, 2003: 4), the natural science learning area deals with the promotion of scientific literacy. This is achieved by developing and using -

... science process skills, critical thinking skills and problem-solving skills in a variety of settings, developing and applying scientific knowledge and understanding and appreciating the relationships and responsibilities between science, society and the environment (DoE 2003: 4).

The RNCS also maintains that the natural science learning area must be able to provide a foundation on which learners can build throughout life.

At the foundation phase level, the curriculum consists of three learning programmes, namely literacy, numeracy, and life skills. This study was conceptualised while the RNCS (DoE, 2003) was the official policy document with the result that reference is still made to "learning outcomes and assessment standards". The Curriculum and Assessment Policy Statement (CAPS) came into effect in January 2012. This document attempts to facilitate interpretation of the National Curriculum Statement (NCS) and does so by removing notions of 'learning outcomes', 'assessment standards' and 'learning programmes' from the curriculum. The implications for the foundation phase are the consolidation of six learning areas into study areas under the 
umbrella of 'life skills' as a curriculum component (DoE, 2011: 5). In this configuration 'natural science', as a learning area, is included as a component of 'Beginning Knowledge'. While this may appear to be a major change, the fact is that emphasis in science learning is still on inquiry learning and problem solving, with limited formalised conceptual learning. In both the RNCS and the CAPS the weekly allocation for science is quite limited making this study as relevant now as it was when it was conceptualised.

In the foundation phase, natural science has not traditionally been seen as a focus of instruction. Many reasons could be attributed to this: having no specific curriculum for teachers to follow, teachers' lack of content knowledge, the issue of unavailability of resources, large class sizes, teacher identity and teacher confidence are some of the reasons that could be offered. Other problems that may well contribute to this could be the background of the teachers and the fact that science is integrated in the life skills learning programme. Although the RNCS (DoE, 2003) has natural science as a mandatory component of the life skills learning programme, it fails to clearly define how scientific investigations can be integrated within the foundation phase classroom.

Our experiences during the professional practice of student teachers made us aware of the fact that natural science was not a priority area in the foundation phase. In fact, student teachers were often adamant that natural science is not taught in the foundation phase. When visiting student teachers during the professional practice we observed them teaching science lessons in the way they were instructed to do so by their mentor teachers. Our experience of working with foundation phase school teachers confirms this. Teachers were heard to say:

The basic thing in our school is mathematics and literacy [...] no one speaks of science $[\ldots]$ science can be rowdy $[. .$.$] it is neglected but what can we do ...$

This prompted this study, as we were curious to find out how natural science is conceptualised by foundation phase teachers.

The research questions, which guided the study, are:

- What are foundation phase teachers' understandings of the natural science curriculum?

- How do teachers' understandings of natural science influence their ability to implement a transformational curriculum?

\section{Review of related literature}

Appleton claims that primary teachers are normally hesitant to teach science (2008). He cites two reasons for this, the first being a limited knowledge of science content as well as a limited science pedagogical content knowledge (PCK) (Appleton, 2008; 2003). Studies that consistently reveal problems with primary science education are a manifestation of the science knowledge held by primary school teachers (Scholtz, Watson \& Amosun, 2004; Sherman \& MacDonald, 2007). The natural science curriculum for the foundation phase emphasises 'investigations' as the most important learning 
outcome. Consequently, at foundation phase level there is only one learning outcome, which states that the -

The learner will be able to act confidently on curiosity about natural phenomena, and to investigate relationships and solve problems in scientific, technological and environmental contexts (DoE, 2003: 6).

Appleton's (2008: 525) study of a professional development programme revealed that elementary or primary school teachers work with pedagogical content knowledge (PCK) in different ways when compared to secondary school teachers. Primary school science teachers usually start with the idea that science teaching should be activitybased and work from specific activity ideas. He goes on to explain it is not surprising that the majority of primary school teachers tend to have limited knowledge in both science content knowledge and in science PCK, given that few primary school teachers are science discipline specialists. foundation phase teachers may lack confidence in their abilities to teach science because of incomplete content knowledge (Akerson \& Flaningan, 2000; Borko, 1993; Smith \& Neale, 1989). Those lacking confidence tend to engage in avoidance behaviour, such as not teaching science at all or teaching a version of science that more closely resembles such subjects as language and social studies (Appleton, 2008: 525).

While foundation phase teachers in the South African context are not required to teach science content to learners, teachers need adequate content knowledge to facilitate inquiry learning. A study conducted by Cho, Kim and Choi (2003) on early childhood teachers' attitude to science teaching revealed that "science teaching in early childhood education usually does not require much content knowledge of science". They go on to say: "What early childhood teachers need is not the knowledge, but rather practical approaches that correspond to young children's characteristics" (Cho, Kim \& Choi, 2003: 39). Yilmaz-Tuzun (2008: 188) further elaborates, “... teachers content knowledge can influence what they teach as well as how they teach." It has been reported that -

... teachers who lack content knowledge often resort to lecture instead of using learner centred teaching techniques that produce real student understanding (Grossman, Wilson, \& Shulman, 1989: 27).

Yilmaz-Tuzun (2008: 197) concludes from his study that if -

... teachers know the content well it will be easier for them to choose the appropriate pedagogical activities and teaching methods.

Other reasons given for the marginalisation of science in schools are school contextual factors, such as limited resources for teaching science and perceived priorities in primary schooling afforded to other subjects as compared to science (Appleton, 2003). These reasons are also inherent in South Africa's education system. Currently there is a strong move towards improving basic reading, writing and mathematical skills. As a result, the time spent teaching science especially in the foundation phase has been reduced. Limited resources are a reality in our schools. In the foundation phase, natural science forms a one sixth part of one of the three learning areas, namely life skills. The very idea that natural science has to be integrated within the 
life skills learning programme, which in turn has to be integrated in the foundation phase curriculum, which includes numeracy and literacy, is a source of uncertainty and confusion for teachers.

Foundation phase teachers are viewed as having a specialised body of knowledge which includes knowledge about children, teaching, learning and the curriculum that can be translated into meaningful practice. The teacher must plan learning experiences that engage and challenge children in thinking that is conceptually rich, coherently organised, and persistently knowledge building. An effective foundation phase teacher is going to be one who can facilitate and extend children's learning within the holistic nature of the early childhood curriculum without being overcome by the conventional notions of teaching. In the curriculum area of science, this is particularly difficult since teachers often do not have the requisite background knowledge to integrate content and pedagogy on their own.

Henze, Van Driel and Verloop (2007) claim that teachers' knowledge, determines to a large extent, how they respond to educational innovation. It is, for this reason, necessary for innovators to take this knowledge into account when implementing educational changes. These authors investigated how teachers' pedagogic practices changed in response to a curriculum innovation and what factors affected the ways in which they changed. They explored how physical and social factors interacted with aspects of teachers' own personal histories, such as their experience and training for teaching science, and how these factors affected how they adopted or adapted the curriculum innovation. They concluded that teachers' knowledge will transform steadily over time -

... due to new experiences, in addition, to improve successful implementation high quality teaching materials needs to be applied (Henze, Van Driel \& Verloop, 2007: 120).

From the literature review, it is apparent that various factors influence the way a teacher will approach implementing the natural science curriculum.

\section{Theoretical framework}

Teachers' are expected to teach natural science in an integrated life skills programme by focusing on an inquiry-based, problem-solving approach. The extent to which they are able to do this, depends on their understanding of the curriculum which, in turn, will influence the way they implement the curriculum. Rogan and Grayson (2003) maintain that for curriculum change to occur, both the 'why' (the need for curriculum change) and the 'how' (issues pertaining to the implementation) must be addressed. To accomplish this they suggest a theory of implementation called the Zone of Feasible Innovation (ZFI).

The ZFI is based on Vygotsky's notion of a zone of proximal development (ZPD) (Rogan \& Grayson, 2003: 1195). Analogically this 'zone' is what can be learnt with effective mediation. The ZPD can thus be seen, by way of analogical reasoning in this metaphor, as the (conceptual) 'distance' between the actual development level as 
determined by independent problem solving and the level of potential development as determined through problem solving under adult guidance or in collaboration with more capable peers (Vygotsky, 1998). The ZFI is, in the same form of analogical reasoning, the 'distance' between the actual capacity of the teacher with regard to implementation of a new curriculum and the degree of innovation required by a new curriculum. As with the idea of the ZPD, context is an important factor in determining the complexity of innovation. While curriculum is defined at a macro-level (DoE, 2003), the ZFI is designed to operate at a micro-level. The 'zone of feasible innovation' remains a hypothetical construct in analogical reasoning, which suggests that innovation should not exceed current practice by too large a gap between existing practice and the demands of the innovation, lest the teacher is stretched too rapidly (cf Figure 1).

\section{ZFI}

Current routine practices,

'Ideal' practice, e.g. learner-

e.g. demonstrations

designed, open-ended projects

Figure 1: The location of ZFI.

This theory of implementation, according to Rogan and Grayson (2003: 1178) is based on three major constructs, namely 1) profile of implementation, 2) capacity to support implementation and 3) support from outside agencies. The third construct, support from outside agencies was not addressed in this study which focuses on the teacher and not the curriculum. The profile of implementation is an attempt to comprehend and articulate the degree to which the principles of a set of curriculum proposals are being put into practice. For the purposes of this study, the probable dimensions of the profile of implementation reported on pertain to the teacher only.

The construct, the capacity to support innovation entails the endeavour to comprehend and extend on the factors that are able to sustain, or hamper the implementation of new ideas and practices in a system as a school (Rogan \& Grayson 2003: 1186). Not all schools have the ability to execute a given innovation to the same degree. For the purpose of this study, the focus is only on teacher factors as the capacity to support innovation.

A framework for this study was developed by adapting the theory of implementation proposed by Rogan and Grayson (2003). 


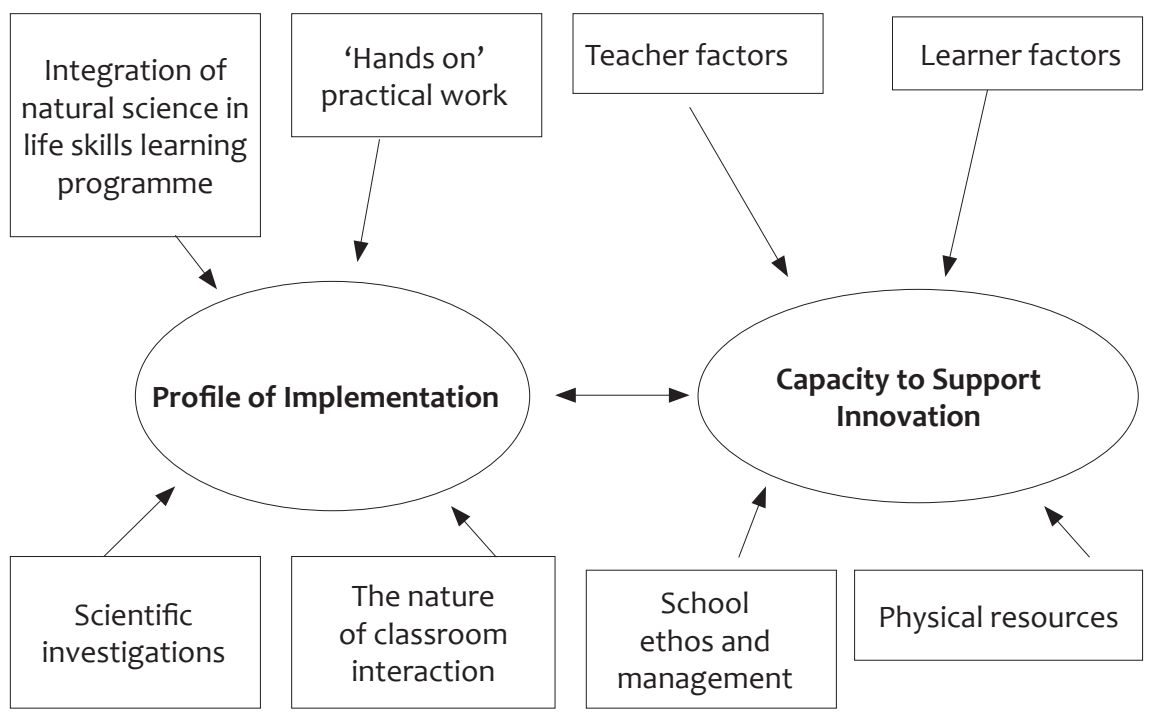

Figure 2: The framework for the study (Rogan, 2007: 99).

\section{Research design and methodology}

A qualitative research design was employed for the purpose of this study, to provide rich descriptions of phenomena under investigation. The style of educational research adopted for this research was a case study. This research initiative used an interpretive methodology in an attempt to comprehend teachers' understanding and implementation of the natural science curriculum in the foundation phase.

In order to obtain data, four foundation phase teachers from Grade R to 3 in one school participated in the study. The research site for this study was an urban school in the greater Durban area. This was historically a school for coloured learners. The learner population is made up of predominantly coloured and African learners. This site was chosen for the study as it is a public school that has Grade R as well as Grades 1,2 and 3

\section{Data collection}

Data was obtained from the questionnaire, semi-structured interviews and a rating scale. The questionnaire supplied data on teachers' content knowledge and instructional methods, as well as teachers' levels of confidence. The interviews served to elaborate on responses obtained from the questionnaire. The questions pertaining to content knowledge and instructional methods were informed by the expectations of the RNCS. An addendum to the questionnaire provided clarification of each instructional method, which was formulated by consulting various sources so that 
there was a common understanding of what was meant by each instructional method (O’Bannon, 2002; Sidhu, 2006; Thomas, 2000).

The rating scale ( $c f$. Appendix A) used in this study was obtained from Cho, Kim and Choi (2003) who developed the scale to measure early childhood teachers' attitude towards science teaching. Although the scale was adapted to be appropriate for this study, the core structure was retained. The rating scale was designed around four sub constructs with a sum of 34 items. The first sub construct had ten items, which measured teachers' confidence in teaching science content. The second sub construct measured teachers' classroom preparation and had 13 items. The third sub construct had six items to measure how teachers' manage 'hands on' science. The fourth subconstruct measured the developmental appropriateness of the science curriculum as perceived by the teachers. Teachers responded to the 25 positive and nine negative items using the three-point Likert Scale from agree to disagree.

In qualitative research, claims of validity rest on the data collection and analysis techniques. To enhance validity in this study a multi-method strategy and mechanically recorded data were used. Multi-method strategies allowed for the triangulation of data across inquiry techniques (Struwig \& Stead, 2004; McMillan \& Schumacher, 2001). Informed consent was obtained from the participants in the research during the planning of the study (Brickhouse, 1992). Permission to conduct research was obtained from various stakeholders and the University of KwaZulu-Natal gave ethical clearance for the research to be conducted.

\section{The teachers}

The four teachers in the study are all females and will hereafter be referred to as Karen, Fiona, Carly and Simone (pseudonyms).

- Karen has 35 years' experience teaching in the foundation phase. She has 38 learners in her Grade R class. She has a three-year Lower Primary Teaching Certificate. She studied Biology at school and the teacher qualification had a general science component. Being 58 years of age she is the oldest participant. She believes that her experiences best qualifies her as a foundation phase teacher. Since there is only one Grade R class, she has to complete all the planning and preparation on her own.

- Fiona has 17 years teaching experience of which 13 years has been in the foundation phase. She has a three-year teaching qualification from a teaching college. She has 47 learners in her Grade one class. She is 44 years old. She sees the benefit of her teaching qualification because in her last year of study she majored in the foundation phase. She has had experience making teaching aids as well making science equipment. She is very confident in her knowledge of the curriculum documents, "I know all my LO's (learning outcomes) in each learning programme and am able to integrate the different learning areas." 
- Carly has 10 years teaching experience of which eight years has been in the foundation phase. She has 44 learners in her Grade two class. She was the youngest teacher. She is 34 years old. She has a four-year qualification and is currently studying towards the Advanced Certificate in Education (ACE). None of her teacher qualifications had a science component. She believes that the workshops she attended on phonics and reading has improved her teaching.

- Simone has 21 years teaching experience of which 20 years has been in the foundation phase. She has 44 learners in her Grade 3 class. She is 43 years old and has a four-year teaching qualification. Simone is of the opinion that -

... having my fourth year ACE and learning integrated education using computers has thoroughly equipped me to teach my learners using computers to do research on the computer. Learners somehow do amazing work when using technology.

\section{Findings}

The findings from the questionnaires are presented in three tables, two of which relate to teachers' understanding of natural science while the third table presents evidence of teachers' confidence levels in teaching natural science. By understanding we mean teachers' views of what should be taught and how it should be taught. Table 1 shows the number of content areas out of 20 topics in the natural science curriculum that each teacher was either, very confident, confident, not so confident and not confident to teach. Where there are no ticks $(\checkmark)$, there were no responses to that content area. The teachers' responses were tallied.

Table 1: The content areas that teachers were confident teaching.

\begin{tabular}{|c|c|c|c|c|c|c|c|c|c|c|c|c|c|c|c|c|}
\hline \multirow{2}{*}{$\begin{array}{c}\begin{array}{c}\text { Content } \\
\text { knowledge }\end{array} \\
\text { Grade } \\
\end{array}$} & \multicolumn{4}{|c|}{ Very Confident } & \multicolumn{4}{|c|}{ Confident } & \multicolumn{4}{|c|}{$\begin{array}{l}\text { Not so } \\
\text { confident }\end{array}$} & \multicolumn{4}{|c|}{ Not confident } \\
\hline & $\mathbf{R}$ & 1 & 2 & 3 & $\mathbf{R}$ & 1 & 2 & 3 & $\mathbf{R}$ & 1 & 2 & 3 & $\mathbf{R}$ & 1 & 2 & 3 \\
\hline $\begin{array}{l}\text { Light energy and } \\
\text { colour }\end{array}$ & & & & & & $\checkmark$ & & & & & & & & & $\checkmark$ & $\checkmark$ \\
\hline Heat energy & & & & & & $\checkmark$ & & & & & & & & & $\checkmark$ & $\checkmark$ \\
\hline Sound energy & & & & & & & & & & $\checkmark$ & & & & & $\checkmark$ & $\checkmark$ \\
\hline Magnetic interactions & & & & & & $\checkmark$ & & & & & & & & & $\checkmark$ & $\checkmark$ \\
\hline Electrical energy & & & & & & & & & & $\checkmark$ & & & & & $\checkmark$ & $\checkmark$ \\
\hline Simple machines & & & & & & & & & & & & & & $\checkmark$ & $\checkmark$ & $\checkmark$ \\
\hline Plants & & & & $\checkmark$ & & $\checkmark$ & & & & & $\checkmark$ & & & & & \\
\hline Animals & & & & $\checkmark$ & & $\checkmark$ & & & & & $\checkmark$ & & & & & \\
\hline Nutrition & $\checkmark$ & $\checkmark$ & & $\checkmark$ & & & & & & & $\checkmark$ & & & & & \\
\hline Air & $\checkmark$ & & & $\checkmark$ & & $\checkmark$ & & & & & $\checkmark$ & & & & & \\
\hline Weather & $\checkmark$ & & & $\checkmark$ & & $\checkmark$ & & & & & $\checkmark$ & & & & & \\
\hline Water & $\checkmark$ & $\checkmark$ & & $\checkmark$ & & & & & & & $\checkmark$ & & & & & \\
\hline Matter and materials & & & & & & & $\checkmark$ & & & & & & & & & $\checkmark$ \\
\hline
\end{tabular}




\begin{tabular}{|c|c|c|c|c|c|c|c|c|c|c|c|c|c|c|c|c|}
\hline $\begin{array}{c}\text { Content } \\
\text { knowledge }\end{array}$ & \multicolumn{4}{|c|}{ Very Confident } & \multicolumn{4}{|c|}{ Confident } & \multicolumn{4}{|c|}{$\begin{array}{l}\text { Not so } \\
\text { confident }\end{array}$} & \multicolumn{4}{|c|}{ Not confident } \\
\hline Grade & $\mathbf{R}$ & 1 & 2 & 3 & $\mathbf{R}$ & 1 & 2 & 3 & $\mathbf{R}$ & 1 & 2 & 3 & $\mathbf{R}$ & 1 & 2 & 3 \\
\hline $\begin{array}{l}\text { Reactions and } \\
\text { changes of materials }\end{array}$ & & & & & & & $\checkmark$ & & & & & & & $\checkmark$ & & $\checkmark$ \\
\hline $\begin{array}{l}\text { Universe and solar } \\
\text { system }\end{array}$ & & & & & & $\checkmark$ & & $\checkmark$ & & & $\checkmark$ & & & & & \\
\hline $\begin{array}{l}\text { Earth and moon } \\
\text { systems }\end{array}$ & & $\checkmark$ & & & & $\checkmark$ & & & & & $\checkmark$ & & & & & $\checkmark$ \\
\hline $\begin{array}{l}\text { Human body } \\
\text { (systems) }\end{array}$ & & $\checkmark$ & & & & $\checkmark$ & $\checkmark$ & $\checkmark$ & & & & & & & & \\
\hline Matter and Motion & & & & & & & & & & $\checkmark$ & $\checkmark$ & & & & & $\checkmark$ \\
\hline Atoms & & & & & & & & & & $\checkmark$ & $\checkmark$ & & & & & $\checkmark$ \\
\hline Ecology & & & & & & & & & & $\checkmark$ & $\checkmark$ & & & & & $\checkmark$ \\
\hline \multicolumn{17}{|l|}{ Other } \\
\hline \multirow{2}{*}{ TOTAL } & 4 & 4 & 0 & 6 & 0 & 10 & 3 & 2 & 0 & 5 & 11 & 0 & 0 & 2 & 6 & 12 \\
\hline & \multicolumn{4}{|c|}{14} & \multicolumn{4}{|c|}{15} & \multicolumn{4}{|c|}{16} & \multicolumn{4}{|c|}{20} \\
\hline
\end{tabular}

Table 1 indicates a noticeable trend in the content areas teachers were confident to teach. These areas were plants, nutrition, air, weather, water and human body systems. They seemed mostly confident teaching biology-related topics rather than physical science-related topics. Teaching these content areas to learners in the foundation phase might seem natural and innate as the natural environment could be used as resource. Therefore, it is surprising that teachers were not confident to teach Ecology. Having studied Biology at school it would seem that Karen and Fiona could have used this knowledge to contribute to their confidence in these content areas. All of the common content areas, except for plants, form part of the Beginning Knowledge in the CAPS documents (DoE, 2011). Environmental awareness forms part of the curriculum from Grade $\mathrm{R}$ to 3 . Teachers' responses in the interviews provide reasons for teaching only particular content topics:

Karen: It is part of the school curriculum. These topics are taught across the grades yearly.

Fiona: Because we teach this. Not confident in the others because maybe we don't teach them.

Carly: It seems to come up a lot depending on our context sometimes it does fall in our context, in our lesson planning.

Simone: We teach this as part of our curriculum.

In addition, there seems to be a relationship between the science content not taught and the teachers' confidence as reflected in their responses:

Karen: Inappropriate to my grade R curriculum. Not part of our curriculum.

Fiona: $\quad$ Most of those that I am not confident. 
Carly: I am not really [...] actually I don't have the (pause) [...] how can I put it the knowledge. I don't know much with these areas. It also has not been part of our planning.

Simone: $\quad$ Not relevant to the curriculum for Grade 3.

There does not seem to be much change in the basic content areas from year to year, although the content is rotated between the grades. Fiona said:

We change content every year. Like if we teach animals, we could do pets and the next year we could do wild animals. That's how it works in the foundation phase. If we teach pets, Grade 2 will teach wild animals and Grade 3 will teach care of pets and wild animals. And we will swop. Grades 3's tie it up.

Whether this confidence is due to the fact that they have taught these topics over many years or whether they select topics to teach that they are confident to teach, is not clear. If the second reason applies, teachers will be reluctant to start teaching new topics and this limits their ability to teach across a range of topics, including those topics that may be taught using an investigative approach. Their argument that it is in the curriculum does not hold, as the curriculum is not that limited. It seems as if this particular group of teachers have selected certain topics and constructed their lessons around it. They have in a sense designed their own curriculum to suit their context and their abilities.

Table 2 shows the frequency of the different instructional methods the teachers use to teach science. The teachers' responses were tallied.

The frequency of the instructional methods reveals the manner in which teachers believe natural science should be taught and is an outcome of their understanding of natural science. The common instructional method used by all teachers is discussion. Discussion is a passive process where the learners are usually seated and are not actively involved in the learning process. Teachers seem to believe that discussions "stimulate learners thinking and imagination" and "bring out the knowledge".

'Hands on' was the next instructional method that was used by all teachers. This suggests that teachers do believe that learners need to be actively involved in learning. From the interviews teachers explained that they do hands on activities, because "they (the learners) must experience it". From the rating scales completed by the teachers, they all agreed that they did not mind the messiness created when doing 'hands on' science and that they are comfortable using any classroom materials for science activities. The instructional methods not used were inquiry, scientific investigations, laboratory and graphic organisers. According to the RNCS there is only one learning outcome in the foundation phase, which is Scientific Investigations (DoE, 2003). The teacher's guide for the development of learning programmes realises that there needs to be transformation in the pedagogy of science teaching and suggests the transformation be "characterised by investigations being placed at the centre of all classroom activities" (DoE, 2003: 27). It is understandable that teachers did not use a laboratory as the school does not have one. 
Table 2: Frequency of instructional methods used by each teacher.

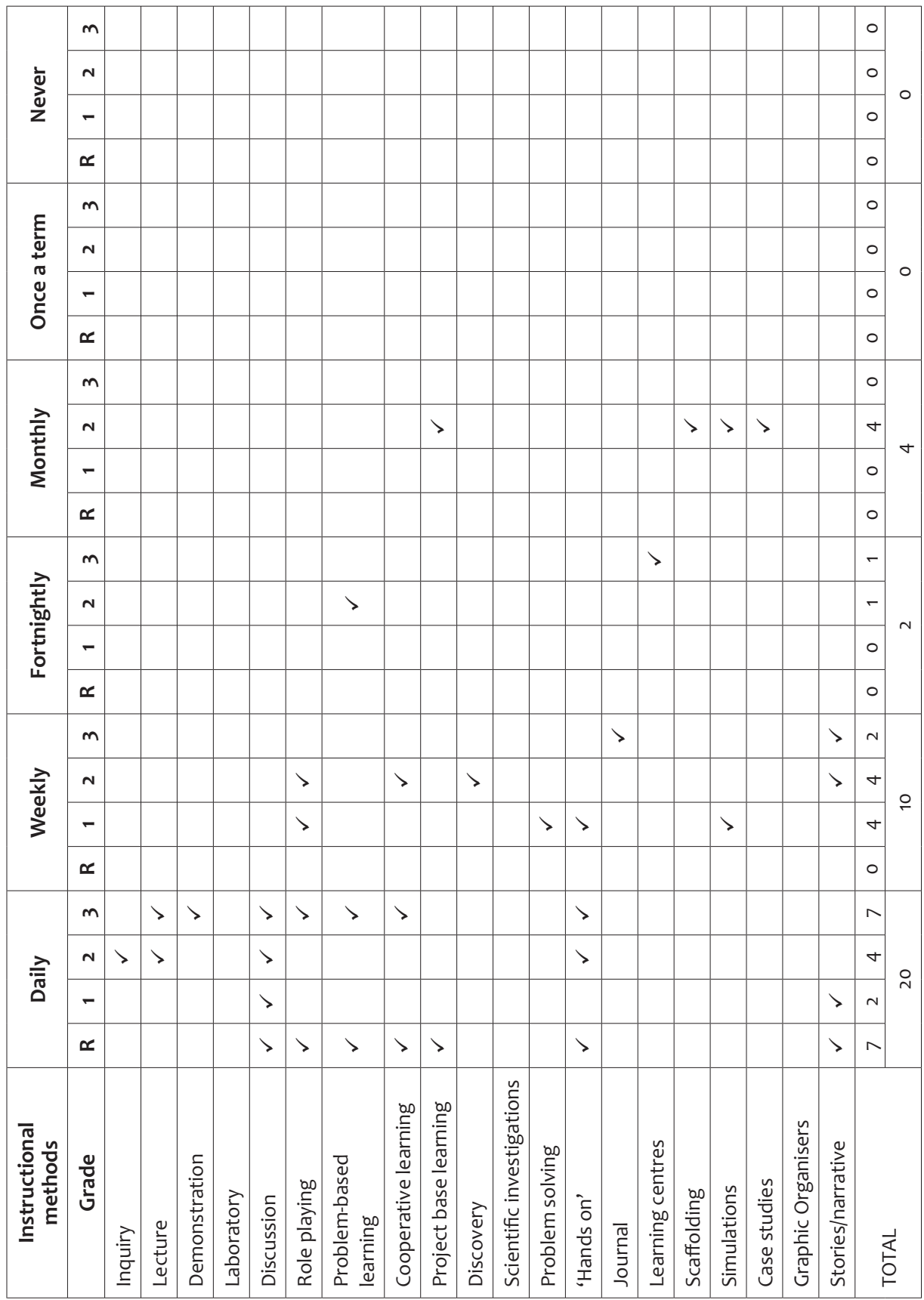


Evidence from the rating scales suggest that two out of the four teachers (Karen and Carly) feel they have the necessary skills to teach science and are comfortable doing science activities; the other two teachers (Fiona and Simone) are undecided. Three out of the four teachers (Karen, Fiona and Carly) fear science activities would not turn out as expected and they have a difficult time understanding science although they enjoy it. All the teachers agree that they are able to answer learners' science questions and when they teach science they welcome learners' questions. Teachers' choice of instructional methods fit the curriculum as determined by the teachers. If teachers are not willing or able to introduce topics that lend themselves to inquiry learning, there is little chance that this will happen.

When teachers were asked whether their learners would be able to conduct investigations, there was a common thread in their responses:

Karen: I think so. They will love that.

Fiona: Absolutely, Absolutely, Absolutely!

Carly: $\quad$ Not all of them. Depending on their levels, they are at because they are all at different levels. The bright children, maybe a third of them will be able to, but the middle group will be able to, but they won't be so sufficient like the first group. The last group really struggles.

Simone: $\quad$ No. No they would, with guidance. They are very eager and they are willing to learn. They are like sponges they suck up anything.

The teachers did believe that their learners were capable of carrying out investigations and yet none of them selected scientific investigations as an instructional method for teaching science. It was only Carly who thought that only her 'bright' learners would be able to carry out investigations.

Teachers were asked to identify the characteristics that best describes them as a foundation phase teacher teaching natural science. The characteristics, included dedication, caring, well qualified, experience, attends professional development activities, confidence, approachable, tries innovative teaching techniques, plans lessons well, sound science content knowledge, conscientious attendance, committed make an extra effort to improve teaching, competent and sound science pedagogical content knowledge. From the data, it is evident that the teachers have a very good image of themselves. Out of the 15 characteristics, the only two that all teachers did describe themselves as not having were sound "science content knowledge" and "sound science pedagogical content knowledge". Fiona was the only teacher that represented herself as having all the characteristics. Teachers commented on their choice of characteristics that best describes them:

Karen: $\quad$ Experience and been at it for so long.

Fiona: $\quad$ You have to be well qualified although I am not well qualified but I think dedication comes in there as well and the willingness to constantly keep abreast with new educational issues and learning materials. Science content knowledge is absolutely necessary. You must have sound knowledge and to an extent I know the degree of complexity changes from Grade One in comparison to high school but my knowledge must 
at least $[\ldots]$ for although it is limited for the grade ones I must know what I am talking about.

Carly: $\quad$ All except sound science content knowledge and sound science pedagogical (teaching) content knowledge. Maybe I still need more practice in the science field. Not that I can't - I think I just need to get more knowledge.

Simone: I would like to improve my science content knowledge as I am not confident in this learning area, however, I do try to do my best.

None of the participants see natural science as their greatest strength, nor do they see lack of science knowledge as a great weakness for a foundation phase teacher. Only one teacher suggested "She neglects life skills". The two factors that teachers are least confident in are two crucial factors as they determine the teacher's capacity to implement innovative curriculum changes and teach to those changes.

\section{Discussion and conclusion}

The purpose of this study was to gain insight into foundation phase teachers' understanding of their natural science foundation phase curriculum. Teachers' understanding of science will influence their capacity to implement innovative curriculum changes.

A relationship exists between teachers' choice of content and their confidence to teach the content. The content taught by these teachers is content that they have been engaging with for many years. Although teacher knowledge is correlated to -

... individual experiences and circumstances, there are features, which are shared by groups of teachers who are in similar situations (Henze, Van Driel, \& Verloop, 2007: 102).

In this study, the group of teachers are in the same school and in the same foundation phase department. Their understanding of natural science appears to be limited as they believe they are teaching all that the curriculum requires of them. They do not appear to consider the possibilities of introducing different topics into the curriculum. The fact that they work and plan together is commendable, but it does seem to hamper their inclination to be more innovative as they are all very comfortable with the status quo. Their planning is done together hence they are knowledgeable and confident in the same content areas. The capacity to support a new curriculum is dependent on a number of factors; teachers competence being one of them. This study shows that one of the teacher factors, i.e. content knowledge, is not strong and this restricts the teachers' ability to implement innovative curriculum changes.

With regard to the profile of implementation, teachers' use of instructional methods to teach science is not indicative of an inquiry-based approach to teaching science and especially scientific investigations, which is the only natural science outcome in the foundation phase. However, teachers do believe that their learners are able to conduct investigations and a 'hands on' approach to teaching science should 
be encouraged. If teachers had confidence to teach more content areas then they may develop the competence to select suitable instructional methods that promote inquiry. Studies have shown that knowledge of content to teach will make it easier for teachers to choose the most appropriate instructional method (Shulman, 1986; Yilmaz-Tuzun, 2008). Teachers are influenced to teach science in the manner that they do, because of their limited experience of teaching science. These teachers are not science specialists, but received their training as foundation phase teachers. Although they see the value of science and know that 'hands-on' methods of inquiry should be promoted they do not have the content knowledge to implement it.

Considering the profile of implementation with regard to natural science teaching, as well as the teachers' capacity to innovate the curriculum, the question arises where these teachers are situated within the ZFI? Are they moving towards 'ideal practice' and how far are they from 'ideal practice'? Answers to the research questions give us some indication of where these teachers may be: They do not have a broad spectrum of science content knowledge and this influences their instructional practices. While they are willing to try 'hands-on' activities, their ZFI is closer to traditional discussion practices than to innovative scientific investigative approaches.

Suitably designed teacher in-service training that focuses science teaching at foundation phase level may contribute to increasing teachers' confidence in teaching science. Subject content knowledge, instructional methods and the integration of natural science in the foundation phase learning programmes should form part of the in-service training. Appleton (2003: 18) reports that "Teacher education programmes have also received criticism for not preparing teachers adequately." The enthusiasm and confidence with which these teachers appear to approach science teaching is encouraging. Increasing confidence through improved science knowledge may lead to more appropriate instructional methods which would enable them to expand their ZFI. In the South African context, where teachers have been subjected to considerable curriculum change, defining the ZFI in different contexts may serve and important purpose in assisting teachers to cope with such changes.

\section{References}

Akerson, V. L. \& Flaningan, J. (2000). Preparing preservice teachers to use an interdisciplinary approach to science and language arts instruction. Journal of Science Teacher Education, 11: 287-313.

American Association for the Advancement of Science (AAAS). (1993). Bench marks for scientific literacy. Washington, DC: AAAS.

Appleton, K. (2008). Developing science pedagogical content knowledge through mentoring elementary teachers. Journal of Science Teacher Education, 19: 523-545.

Appleton, K. (2003). How do beginning primary school teachers cope with science? Towards and understanding of science teaching practice. Research in Science Education, 33: 1-25. 
Borko, H. (1993). The integration of content and pedagogy in teaching. In A. L. Gardner and K. F. Cochran (eds.), Critical issues in reforming elementary teacher preparation in mathematics and science. Greeley, CO: University of Colorado, pp. 25-45.

Boshoff, N. \& Mouton, J. (2003). Science policy indicators. Human Resource Development Review: Education, Employment and Skills in South Africa. South Africa: HSRC Press.

Braund, M. \& Reiss, M. (2006). Towards a more authentic science curriculum: The contribution of out-of-school learning. International Journal of Science Education, 28(12): 1373-1388.

Brickhouse, N. W. (1992). Ethics in field-based research: Ethical principles and relational considerations. Science Education, 76(1): 93-103.

Cho H. S., Kim, J. \& Choi, D. H. (2003). Early childhood teachers' attitude towards science teaching: A scale validation study. Educational Research Quarterly, 27(2): 33-44.

Department of Education (DoE). (2011). Curriculum and Assessment Policy Statement (CAPS). Life skills for the foundation phase. Pretoria: DoE.

Department of Education (DoE). (2003). Revised National Curriculum Statement, Grade R-9 (Schools) Policy. Teacher's guide for the development of learning programmes, foundation phase. Pretoria: Government Printer.

Department of Education and Employment. (1999). The National Curriculum for England: key stages 1-4. London: Qualifications and Curriculum Authority.

Grossman, P. L., Wilson, S. M. \& Shulman, L. S. (1989). Teachers of substance: Subject matter knowledge for teaching. In M. C. Reynolds (ed.), Knowledge base for the beginning teacher. Oxford, UK: Pergamon Press, pp. 23-36.

Henze, I., Van Driel, J. H. \& Verloop, N. (2007). Science teachers' knowledge about teaching models and modelling in the context of a new syllabus on public understanding of science. Research in Science Education, 37: 99-122.

McMillan, J. H. \& Schumacher, S. (2001). Research in education: A conceptual introduction ( $5^{\text {th }}$ ed.) USA: Addison, Weley, Longman.

Ministry of Education. (2009) The New Zealand Curriculum Framework. [Online.] Available from: http://www.tki.org.nz/r/governance/nzcf/index_e.php. (Accessed 28 July 2009.)

National Research Council. (1996). National science education standards. Washington: National Academy Press.

O’Bannon, B. (2002). Planning for Instruction: Instructional method. [Online.] Available from: http://itc.utk.edu/ bobannon/in_strategies.html\#demonstration. (Accessed 17 October 2010.)

Review Committee on Curriculum 2005. (2000). A South African curriculum for the $21^{\text {st }}$ century.

Rogan, J. M. (2007). An uncertain harvest: a case study of implementation of innovation. Journal of Curriculum Studies, 39(1): 97-121. 
Rogan, J. M. \& Grayson, D. J. (2003). Towards a theory of curriculum implementation with particular reference to science education in developing countries. International Journal of Science Education, 25(100): 1171-1204.

Scholtz, Z., Watson, R. \& Amosun, O. (2004). Investigating science teachers' response to curriculum innovation. African Journal of Research in Science, Mathematics and Technology Education, 8(1): 41-52.

Sherman, A. \& MacDonald, L. (2007). Pre-service teachers' experiences with a science education module. Journal of Science Teacher Education, 18: 525-541.

Shulman, L. (1986). Those who understand: Knowledge growth in teaching. Educational Researcher, 15(2): 4-14.

Sidhu, K. S. (2006). The teaching of mathematics. Sterling Publishers: India.

Smith D. C. \& Neale, D. C. (1989). The construction of subject matter knowledge in primary science teaching. Teaching and teacher education, 5(1): 1-20.

Struwig, F. W. \& Stead, G. B. (2004). Planning, designing and reporting research. Maskew Miller Longman: Cape Town.

Thomas, J. T. (2000). A review of research on project-based learning. [Online.] Available from: http://www.bobpearlman.org/BestPractices/PBL_Research.pdf. (Accessed 7 November 2009.)

Vygotsky, L. S. (1998). The collected works of L. S. Vygotsky. Child Psychology. 5, Riebert, R.W. (ed.). New York: Plenum Press.

Yilmaz-Tuzun, O. (2008). Preservice teachers' beliefs about science. Journal of Science Teacher Education, 19: 183-204. 


\section{Appendix A}

Rating Scale: Teaching natural science in the foundation phase: Teachers' understanding of the natural science curriculum.

\begin{tabular}{|c|c|c|c|c|}
\hline Items & & Agree & Undecided & Disagree \\
\hline \multicolumn{5}{|c|}{ Confidence } \\
\hline & I have the necessary skills to teach science. & & & \\
\hline & $\begin{array}{l}\text { I feel comfortable doing science activities in my } \\
\text { classroom. }\end{array}$ & & & \\
\hline & $\begin{array}{l}\text { I fear science activities would not turn out as } \\
\text { expected. }\end{array}$ & & & \\
\hline & $\begin{array}{l}\text { I understand science concepts well enough to } \\
\text { effectively teach science. }\end{array}$ & & & \\
\hline & $\begin{array}{l}\text { I find it difficult to explain to learners some } \\
\text { science concepts. }\end{array}$ & & & \\
\hline & $\begin{array}{l}\text { I am typically able to answer learners' science } \\
\text { questions. }\end{array}$ & & & \\
\hline & $\begin{array}{l}\text { Given a choice, I would not invite the principal/ } \\
\text { head of department to evaluate my science } \\
\text { teaching. }\end{array}$ & & & \\
\hline & I have a difficult time understanding science. & & & \\
\hline & I enjoy teaching science. & & & \\
\hline & $\begin{array}{l}\text { When teaching science, I usually welcome } \\
\text { student questions. }\end{array}$ & & & \\
\hline \multicolumn{5}{|c|}{ Classroom preparation } \\
\hline & $\begin{array}{l}\text { I enjoy reading resource books to obtain ideas } \\
\text { about science activities for young children. }\end{array}$ & & & \\
\hline & $\begin{array}{l}\text { I am willing to spend time setting up materials } \\
\text { for scientific exploration. }\end{array}$ & & & \\
\hline & $\begin{array}{l}\text { I am happy to help children construct science } \\
\text { equipment for hands-on science. }\end{array}$ & & & \\
\hline & Teaching science takes too much time. & & & \\
\hline & $\begin{array}{l}\text { I am ready to learn and use scientific knowledge } \\
\text { and skills for planning hands on science. }\end{array}$ & & & \\
\hline & $\begin{array}{l}\text { I like to discuss ideas and issues of science } \\
\text { teaching with my colleagues. }\end{array}$ & & & \\
\hline & Teaching science takes too much effort. & & & \\
\hline & $\begin{array}{l}\text { I am familiar with raising open-ended questions } \\
\text { to encouraging children's scientific exploration. }\end{array}$ & & & \\
\hline & $\begin{array}{l}\text { I use many hands- on activities to help my } \\
\text { learners learn science. }\end{array}$ & & & \\
\hline
\end{tabular}




\begin{tabular}{|c|c|c|c|c|}
\hline Items & & Agree & Undecided & Disagree \\
\hline & $\begin{array}{l}\text { I am able to take my learners outside the } \\
\text { classroom to learn science. }\end{array}$ & & & \\
\hline & $\begin{array}{l}\text { Preparation for science teaching generally takes } \\
\text { more time than other subject areas. }\end{array}$ & & & \\
\hline \multicolumn{5}{|c|}{ Classroom preparation } \\
\hline & I integrate science into other subject areas. & & & \\
\hline & I integrate other subject areas into science. & & & \\
\hline \multicolumn{5}{|c|}{ Managing 'hands-on' science } \\
\hline & $\begin{array}{l}\text { I am not afraid of demonstrating experimental } \\
\text { procedures in the classroom }\end{array}$ & & & \\
\hline & $\begin{array}{l}\text { I enjoy collecting materials and objects to use in } \\
\text { my science teaching. }\end{array}$ & & & \\
\hline & $\begin{array}{l}\text { I am interested in handling certain animals and } \\
\text { insects to teach science. }\end{array}$ & & & \\
\hline & $\begin{array}{l}\text { I am comfortable using any classroom materials } \\
\text { (e.g., blocks, toys, boxes, etc.) for science } \\
\text { activities. }\end{array}$ & & & \\
\hline & $\begin{array}{l}\text { I do not mind the messiness created when doing } \\
\text { hands-on science in my classroom. }\end{array}$ & & & \\
\hline & Teaching of science process is important. & & & \\
\hline \multicolumn{5}{|c|}{ Developmental appropriateness } \\
\hline & $\begin{array}{l}\text { I do not believe it is appropriate to introduce } \\
\text { science to children at an early age. }\end{array}$ & & & \\
\hline & $\begin{array}{l}\text { I am comfortable with determining the science } \\
\text { curriculum that is developmentally appropriate } \\
\text { for young children. }\end{array}$ & & & \\
\hline & $\begin{array}{l}\text { I do not feel that young children are curious } \\
\text { about scientific concepts and phenomena }\end{array}$ & & & \\
\hline & $\begin{array}{l}\text { I am familiar with the processes and ways that } \\
\text { young children learn science. }\end{array}$ & & & \\
\hline & $\begin{array}{l}\text { I feel that young children cannot learn science } \\
\text { until they are able to read. }\end{array}$ & & & \\
\hline
\end{tabular}

